\title{
Is Emotional Intelligence Matter in Youth Entrepreneur?
}

\author{
Saparila Worokinasih*, Nila Firdausi Nuzula, Cacik Rut Damayanti, Sumainah Fauziah, Ina Syarifah \\ Department of Business Administration \\ Universitas Brawijaya \\ Malang, Indonesia \\ *saparila.fia@ub.ac.id,nilafia@ub.ac.id, cacik@ub.ac.id, sfauziah.712@gmail.com,ina.syrfh@gmail.com
}

\begin{abstract}
This study aims to determine the factors that influence financial behavior in youth's entrepreneurs in East Java, Indonesia. The focus of the research is young entrepreneurs, because the high rates of unsustainability of this group. It is presumed that the lack of knowledge, ability and skill on their financial basic financial has been factors affecting their business' failure. It also assumes that the success of an entrepreneur is determined by how they make the right decisions in their business. The last factor can be influenced by how they manage their emotions (both emotions for themselves and emotions in others). The combination between I-E-O (InputEnvironment-Outcome) models and Theory Reasoned Action will be used to explain how the entrepreneur behavior in term of financial management. The data was collected through the survey on 200 young entrepreneurs in East Java. Data analysis used the Structural Equational Model (SEM) with the Partial Least Square (PLS) approach. The result is that there is a significant direct and indirect effect between financial literacy and emotional intelligence on financial behavior in youth's entrepreneurs. It can be concluded that very important for young entrepreneur to maintain their financial literacy as well as manage their emotional intelligent in order to make their business successful and sustainable.
\end{abstract}

Keywords-youth entrepreneur, emotional intelligent, financial literacy

\section{INTRODUCTION}

People is related with financial decisions, both personal or business' interests. Failure in the process of managing financial aspect will make a serious consequence in a long term financial as well as the corporate and society [1]. Good financial behaviour will lead to someone's success and build their competitive advantage.

Financial behaviour is very necessary for young generation. This group often start to build their career as entrepreneur since they're in collage, but the responsibility of managing financial planner is low [2]. However, they are rarely practice in basic financial skills, such as, budgeting, regular saving, or long-term investment. This phenomenon is caused by their unpreparedness regarding technical as well as psychological abilities, such as high debt, caused increase of stress level and decrease the psychological satisfaction. Empirical evidence shows that financial literacy has a positive impact on entrepreneur individual behaviour. It is important to understand financial concept that will help in calculate the risk in business operation such as tracking expenses, income and investment choice $[3,4]$. As a whole concept, entrepreneur need to make a plan starting a company and basically for all of this is need a financial literacy.

Moreover, entrepreneur need to develop their emotional intelligence in order to sharp the intuition [5]. By having a good emotional intelligence, they are able to see the opportunities, make difficult conditions easy and explore them to get the advantages. Someone with good emotional intelligence will be able to control any conflicts.

Based on Bahadori [6], people with high emotional intelligence (EI) capable to solve the problem better and efficient since they are able to control their emotion. Brandstätter [7] found that the owner who is also the founder has more stable emotions than the owner who has taken over their business from their parents, siblings, or from the marriage. Entrepreneur who independent and has a stable emotion tends to more successful. However, Yitshaki and Rothsein [8] found that EI did not have direct influence toward the organizational performance, on the contrary there is a direct effect of managerial style on the performance.

The combination of two models, which is I-E-O Model (Input-Environment-Outcome) that is found by Alexander Astin [9] and the Theory Reasoned Actions [10] provide a comprehensive explanation in financial literacy level and emotional intelligence condition. also how's between two factors be able to impact someone to take a decision managing their finance. The result from this model expected to contribute on financial development for young entrepreneur to maintain their initial business to be sustainable. This study focus on the financial behavior in college student who represent as a educate young generation and having a environment that support the entrepreneur activity so that it will be able to become entrepreneur development model that will be continue by increasing financial behavior positively. 


\section{RELATED WORK}

\section{A. Theory of Reasoned Actions (TRA)}

Based on the Theory of Reasoned Actions (TRA), behavior is determined by attitude towards behavior and the influence of other people's opinions which is called by subjective norm. Attitude is formed through belief; it is about what people's thought and the motivation to obedient this people [11]. Means that people tend to engage in behavior that is evaluated as a positively and popular by other people. They tend to hold back toward the behavior that is reputed give no advantage and it is not popular with others. If it is positive behavior, so the behavior will be good, and suitable to practiced and someone will practice it.

There are two powers of Theory Reasoned Actions. First, this model helps people to understand about individual attitude. Secondly, the theory helps to find the reason why people has this attitude and how the attitude could be changed [10]. Behaviour, as a main predictor, is a belief that hold somebody in order to consider certain behaviour, while subjective norm reference to social pressure related with certain people as an individual life which is influenced to take that certain behaviour. In other words, attitude refers to how long some people having a favourable evaluations and judgments or unfavourable from the behavior in question [10]. Second is subjective norm, which is refer to social pressure related with certain people as an individual life which is influenced to take that certain behavior. And the last antecedent is taking control towards the behavior which is perception with the potential factors that facilitate or obstruct behavior performance.

\section{B. Financial Management Behavior}

Financial Management Behavior (FMB) is in the area of financial discipline. FMB is as a determination, acquisition, allocation, and use of financial resources, usually with an overall objective [12], and aligning individual motives and corporate's goals [20]. Furthermore, financial management is primarily concerned with the effective management of funds that increase the financial prosperity positively. The failure of personal financial management refers to long-term social problem negatively, and other social consequences [1].

\section{Financial Literacy}

Financial literacy is a personal's ability to understand and able to apply basic financial concepts [12]. Based on this concept, financial literacy has two dimensions: knowledge, which represents personal financial knowledge from financial education, and application, which refers to the management of personal financial knowledge [1]. In this context, as an individual could have financial knowledge, but to be considered literate, he/she must have ability and confidence to implement it when make some decisions. Therefore, financial literacy is deeper than the basic concepts of financial education or financial knowledge [4,5]. Financial knowledge alone is not sufficient for effective financial management, since the effect of financial knowledge on behavior is measured through behavior in managing finance $[4,12]$.

\section{Emotional Intelligent}

Emotional intelligence becomes a prefix to have result of a good quality performance. It's simply whether it is good or not the performance that has been done directly or indirectly that all influenced by the quality of the emotional intelligence. The strength of emotional intelligence that somebody has, impact against risk-taking behavior [8]. Emotional intelligence is defined as a personal's ability to realize and express their own emotion and others, be able to motivate himself, able to catch the signal which has been sent through another relation, also able to manage their own emotion. People with a good emotional intelligence able to control their emotion when they are get mad, sensitive with other's feeling, and etc.

\section{E. Financial Behavior}

Finance behavior is defined as a human behavior related with managing their money [12]. As an individual, they need a knowledge about a financial decision making that will increase the quality of life in the future. People will acts their behavior based on the application of their knowledge. In study of Deacon and Firebaugh [13], personal finance management is defined as a set of behavior done by making some planning, realization, and evaluating include in cash flow analysis credit, investment, insurance, and pension, and plantation planning. Xiao [12] calculate the personal financial management in relation with cash flow analysis, credit, saving and investment management. Many of previous researches in Vietnam researched one dimension in financial behavior management such as credit card or saving [1]. But, to measure several domains in management behavior is important since every domain has their unique character [12]. This research expands previous study to find the factors that influence financial management behavior of young entrepreneur.

Based on this theories and literature was tested, this is the concept model of this research (Figure 1).

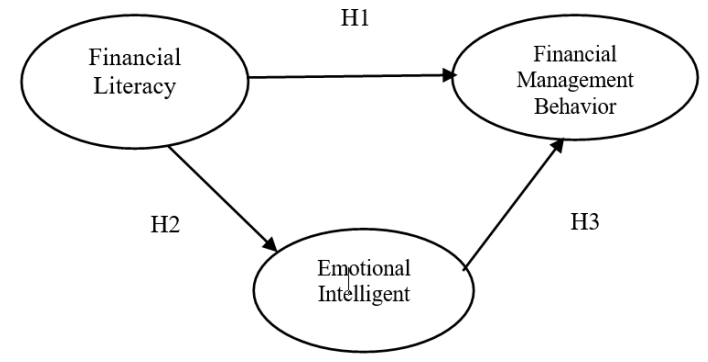

Fig. 1. Research hypothesis model

The proposed hypothesis this research as a follows:

Hypothesis 1. The financial literacy effects the financial management behavior on youth's entrepreneur

Hypothesis 2. The financial literacy effects the emotional intelligent on youth's entrepreneur. 
Hypothesis 3. The emotional intelligent effects the financial management behavior on youth's entrepreneur.

\section{MethODOLOGY}

This research used quantitative and explorative descriptive approach with the survey method. This approach is in order to give description based on indications and phenomenon happen in general field [11]. However, this research aimed to explain the influence between variables by doing hypothesis experiment. Unit analysis on this research is individual in research location.

The population of this research are undergraduate students who carried out entrepreneurial activities in East Java. There are 5 (five) state universities with " $A$ " accreditation (BAN-PT), were selected as research locations, namely: UPN Surabaya, UNESA, UNAIR, UB and UM. Random sampling is used as sampling method. Determination of the number of samples using the Roscoe formula, which is at least 10 times the number of variables studied and / or it is multiples with $5 \%$ as error degree. The total sample is 150 respondents. The primary data is used in this research and collected by distributing questionnaires to students who are entrepreneurs in the research area.

Both descriptive as well as inferential are used to analyze the data. The research hypothesis was tested using the Structural Equation Model (SEM) with Partial Least Square (PLS). SEM is a multivariate analysis technique which is combined between factor analysis and regression analysis (correlation) which purpose to test the relationship between variables in a model, whether it is between indicators and constructs or relation between the constructs [11]. The PLS Technique is carried out in two stages, first stage is a measurement model, this is validated testing and reliability constructs of each indicator. The second stage is the structural model test which purposes to determine whether there is an influence between the measured constructs.

\section{RESULTS AND DISCUSSION}

Total respondents in this research are 200 respondents with . Woman are dominated by 116 students $(58 \%)$ and man are 84 or $42 \%$ from total respondents. The table 1 shows respondent's distribution based on the university:

TABLE I. RESPONDENT'S DISTRIBUTION BASED ON THE UNIVERSITY

\begin{tabular}{|l|l|l|}
\hline \multicolumn{1}{|c|}{ University } & $\begin{array}{c}\text { Frequency } \\
\text { (personal) }\end{array}$ & $\begin{array}{c}\text { Percentage } \\
(\mathbf{\%})\end{array}$ \\
\hline ITS & 50 & 25.0 \\
\hline UB & 50 & 25.0 \\
\hline UM & 50 & 25.0 \\
\hline UNAIR & 50 & 25.0 \\
\hline Total & 200 & $100 \%$ \\
\hline
\end{tabular}

The evaluation of the outer model of this research evaluates the relationship between latent variables with their indicators. There are three latent variables used in this research including
Financial Literacy, Emotional Intelligent, and Financial Management Behavior. Measurements was made in the evaluation of the outer model of this research are Convergent Validity (all indicators have a factor loading value > 0.5), Discriminant Validity (the main cross loading value of the construct Financial Literacy (FL), Emotional Intelligent (EI), and Financial Management Behavior (FMB) is bigger than the correlation value was built from these variables against the other constructs) and Composite Reliability (the value of composite reliability on all variables is $>0.70$ ). The following table 2 shows the evaluation of outer model.

TABLE II. THE EVALUATION OF OUTER MODEL

\begin{tabular}{|l|l|l|l|}
\hline \multicolumn{1}{|c|}{ Variable } & \multicolumn{1}{c|}{$\begin{array}{c}\text { Cronbach's } \\
\text { Alpha }\end{array}$} & $\begin{array}{c}\text { Composite } \\
\text { Reliability }\end{array}$ & \multicolumn{1}{c|}{ (AVE) } \\
\hline Financial Literacy & 0.934 & 0.942 & 0.504 \\
\hline Emotional Intelligent & 0.856 & 0.897 & 0.634 \\
\hline $\begin{array}{l}\text { Financial Management } \\
\text { Behavior }\end{array}$ & 0.917 & 0.930 & 0.507 \\
\hline
\end{tabular}

Primary stage of structural model evaluation is checking the collinearity between construct and predictive ability model [11]. Then it is continuing measure the model prediction ability use four criteria which are determination coefficient $\left(\mathrm{R}^{2}\right)$, where Emotional intelligent (EI) having R-Square about $8.8 \%$, Financial Management Behavior (FMB) having R-square is about 29,2\%; Predictive Relevance (Q2) is about 35,5\%; effect size $\left(\mathrm{f}^{2}\right)$ are influence variable value Financial Literacy (FL) towards variable Emotional Intelligent (EI) is about 0.096, influence of variable value Financial Literacy (FL) towards variable Financial Management Behavior (FMB) about 0.163 and influence of variable value Emotional Intelligent (EI) towards variable Financial Management Behavior (FMB) is about 0,128 . The table 3 shows $\mathrm{R}^{2}$ value that predictive the exogenous variables.

TABLE III. $\quad \mathrm{R}^{2}$ VALUE THAT PREDICTIVE THE EXoGenous VARIABLES

\begin{tabular}{|l|c|}
\hline \multicolumn{1}{|c|}{ Exogenous Variable } & R-Square (R2) \\
\hline Emotional Intelligent (EI) & 0.088 \\
\hline Financial Management Behavior (FMB) & 0.292 \\
\hline
\end{tabular}

Variable path of coefficient value Financial Literacy (FL) to Financial Management Behavior (FMB) is 0.355 with pvalue 0.000 . This result shows that Financial Literacy (FL) has positive and significant effects on Financial Management Behavior (FMB). The path coefficient value variable Financial Literacy (FL) to Emotional Intelligent (EI) is 0.296 with pvalue 0,000 . This result shows that Financial Literacy (FL) has a positive and significant effects on Emotional Intelligent (EI). The variable path of coefficient value Emotional Intelligent (EI) to Financial Management Behavior (FMB) is 0.315 with p-value 0.000. This result shows that Emotional Intelligent (EI) have a positive and significant effects on Financial Management Behavior (FMB). This table 4 shows the significant value of each path. 
TABLE IV. Significant Value of Each Path

\begin{tabular}{|l|l|l|l|l|}
\hline \multicolumn{1}{|c|}{ Variable } & $\begin{array}{c}\text { Standard } \\
\text { Deviation }\end{array}$ & $\begin{array}{c}\text { T } \\
\text { Statistics }\end{array}$ & $\begin{array}{c}\text { P } \\
\text { Values }\end{array}$ & \multicolumn{1}{c|}{ Status } \\
\hline FL -> FMB & 0.063 & 5.629 & 0.000 & Significant \\
\hline FL -> EI & 0.069 & 4.317 & 0.000 & Significant \\
\hline EI -> FMB & 0.072 & 4.392 & 0.000 & Significant \\
\hline
\end{tabular}

There is significantly indirect effect between Financial Literacy, Emotional Intelligent and Financial Management Behavior (0.093 with p-value 0.003 less than 0.5). Hair et,al [11] stated that if the independent variable did not have direct influence on dependent variable after the presence of mediator variable, so it can be categorized as a complete mediation. On the other hand, a partial mediator could be labelling when the effect of independent to dependent variable decrease but significant, after the existence of mediator variable. As result, the mediation role of Emotional Intelligent on Financial Literacy and financial management behavior is a partial mediation. This table 5 shows the value for direct as well as indirect effect of the model.

TABLE V. The VAlue For Direct As Well as INDIRECt EFFeCt of THE MODEL

\begin{tabular}{|l|l|l|l|l|}
\hline Variable & $\begin{array}{c}\text { Standard } \\
\text { Deviation } \\
\text { (STDEV) }\end{array}$ & T Statistics & $\begin{array}{c}\text { P } \\
\text { Values }\end{array}$ & Status \\
\hline $\begin{array}{l}\text { FL -> EI -> } \\
\text { FMB }\end{array}$ & 0.031 & 3.020 & 0.003 & Significant \\
\hline
\end{tabular}

\section{CONCLUSION AND Future SCOPE}

People needs to know about financial knowledge to make a decision that will raise their quality of life. Individual behavior reflects the application from the knowledge [1]. In line with financial behavior and the process itself, it is needed the knowledge in basic concepts of financial as Financial Literacy. The more complete somebody financial knowledge, the higher will be their confidence to take some decisions regarding their financial matter. Consequently, this will decrease the risk of failure.

As a basic knowledge that must be had every person in order be able to survive life in modern society. It cannot be denied that financial literacy is an important thing that must become part of young entrepreneur. The understanding of basic financial concept, which consist of budgeting, saving borrowing, and investing, will contribute to the someone capability and will work up their self-confidence of managing their finance [13]. As a young entrepreneur, the stage of financial knowledge will make more responsible with financial behavior [6]. It appears in high self-confidence in making some decision towards any choices to achieve the purposes of processing the finance.

Except financial factor, making decision on financial also influenced by non-financial factors, such as individual characteristic and social environment [12]. A psychology factor also contributes to make a financial decision process. In line with Framing Theory that how to interpret the information, influenced by culture and the values in society, the formation process is started since was born when human brain still in an empty condition [12]. It means that internal interpretation process is formed by external framework. In line with Cognitive Theory [12] about forming external framework which is include motivation and emotional to perceive and select towards several attentions and memories, next determines how's the information processed and at the end will impact to somebody behavior doing problem solving.

\section{ACKNOWLEDGMENT}

The author thanks to Universitas Brawijaya for providing research grants with Hibah Penelitian Unggulan Scheme in 2020 .

\section{REFERENCES}

[1] Mien, Nguyen and Thao, Tran, "Factors Affecting Personal Financial Management Behaviors: Evidence from Vietnam," Proceedings of the Second Asia-Pacific Conference on Global Business, Economics, Finance and Social Sciences (AP 15 Vietname Coference) , 10-12 July, 2015.

[2] L.M. Borden, S.A. Lee, J. Serido, and D. Collins, "Changing college students' financial knowledge, attitudes, behavior through seminar participation," Journal of Family and Economic Issues, vol. 29, no. 1, pp. 23-40, 2008 .

[3] D. Moore, "Survey of Financial Literacy in Washington State: Knowledge, Attitude and Experiences," Social and Economics Sciences Research Center Technical Report Number 03-39, 2003.

[4] A. Lusardi and O.S. Mitchell, "Planning and financial literacy: how do women fare?", No. w13750, National Bureau of Economic Research, Cambridge, MA, 2008.

[5] Van Rooij, M., Lusardi, A. and Alessi, R. "Financial literacy and stock market participation", Journal of Financial Economics, Vol. 101, No. 2, pp. 449-472, 2011.

[6] M. Bahadori, "The effect of emotional intelligence on entrepreneurial behaviour: A case study in a Medical Science University,” Asian Journal of Business Management, vol 4 issue1, pp. 81-85, 2012.

[7] Brandstätter, "Becoming an entrepreneur - A question of personality structure?", Journal of Economic Psychology, vol. 18, issue 2-3, pp. 157-177, 1997

[8] Yitshaki-Hagai and M. Rothstein, "Does entrepreneurs' emotional intelligence impact performance? The mediating role of managerial style and social capital (interactive paper)", Frontiers of Entrepreneurship Research, vol. 30, issue 4, Article 15. 2011.

[9] A.W. Astin, What matters in college: Four critical years revisited. San Francisco: Jossey-Bass, 1993.

[10] I. Ajzen, and M. Fishbein, Understanding attitudes and predicting social behavior. Englewood Cliffs, NJ: Prentice-Hall, 1980.

[11] J.F. Hair Jr, G.T. Hult, C.M. Ringle and M. Sarstedt, A Primer on Partial Least Squares Structural Equation Modeling (PLS-SEM). (2nd Edition). California: SAGE, 2017.

[12] Xiao, Jing and Dew, Jeffrey, The Financial Management Behavior Scale: Development and Validation, Human Development and Family Studie Faculty Publication, 2011.

[13] R.E. Deacon and F.M. Firebaugh, Family resource management: Principles and applications. Toronto: Allyn \& Bacon, 1988. 